\title{
Fabrication and Characterization of Glimepiride Nanosuspension by Ultrasonication-Assisted Precipitation for Improvement of Oral Bioavailability and in vitro $\alpha$-Glucosidase Inhibition [Corrigendum]
}

Rahim H, Sadiq A, Khan S, et al. Int J Nanomedicine. 2019;14:6287-6296.

The authors have advised there is an error in Figure 4 on page 6292. The unit in part B shows " $\mu \mathrm{m}$ " it should read "nm".
The correct Figure 4 is shown below. The authors apologize for this error.

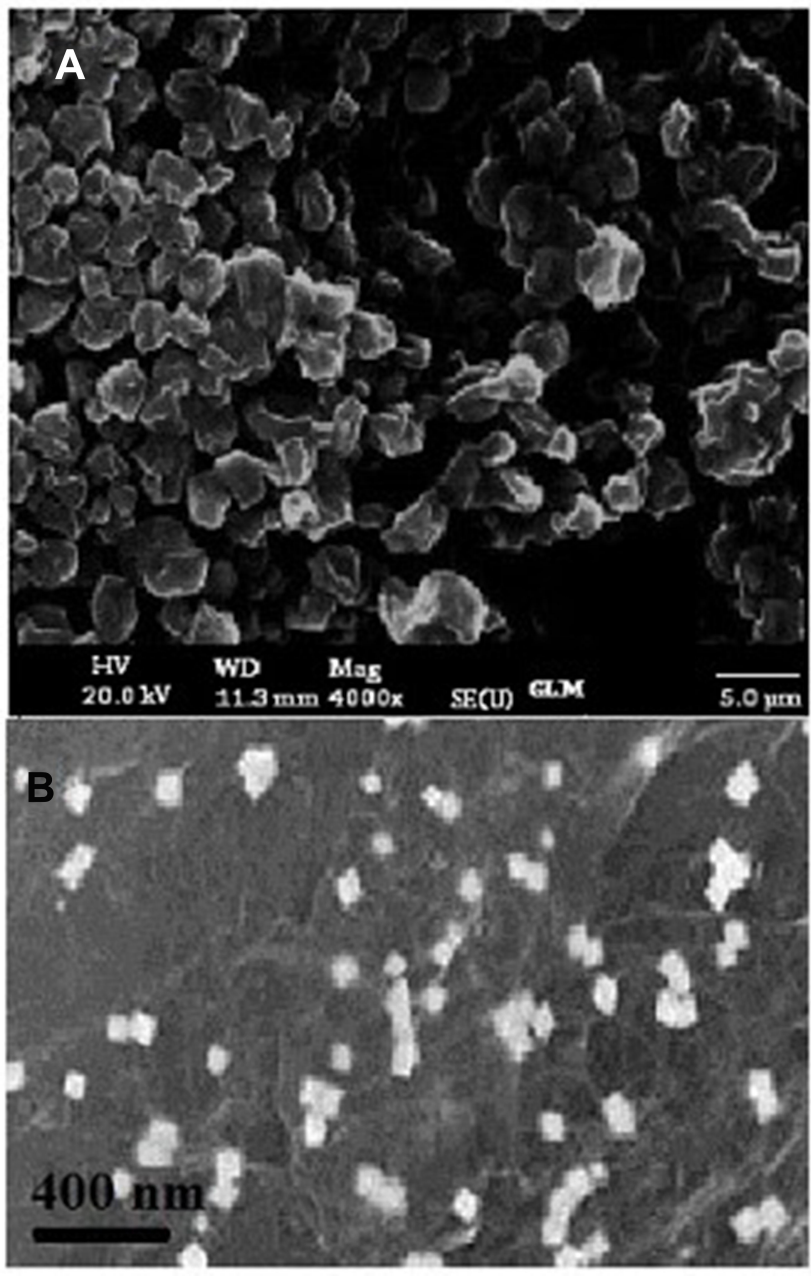

Figure 4 SEM of raw glimepiride (GIm) (A); TEM of GIm nanosuspension (B).

Abbreviations: SEM, scanning electron microscopy; TEM, transmission electron microscopy; HV, high vacuum; WD, working distance.

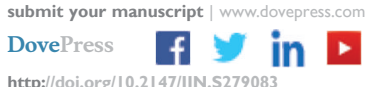

http:/ldoiorg/10.2147/IN. 5279083 


\section{Publish your work in this journal}

The International Journal of Nanomedicine is an international, peerreviewed journal focusing on the application of nanotechnology in diagnostics, therapeutics, and drug delivery systems throughout the biomedical field. This journal is indexed on PubMed Central, MedLine, CAS, SciSearch ${ }^{\mathbb{R}}$, Current Contents ${ }^{\mathbb{B}} /$ Clinical Medicine,
Journal Citation Reports/Science Edition, EMBase, Scopus and the Elsevier Bibliographic databases. The manuscript management system is completely online and includes a very quick and fair peer-review system, which is all easy to use. Visit http://www.dovepress.com/ testimonials.php to read real quotes from published authors. 